\title{
Export of Biomass and Metals from Aquatic to Terrestrial Ecosystems via the Emergence of Odonates (Insecta: Odonata)
}

\author{
O. N. Popova ${ }^{a}$, A. Y. Haritonova, O. V. Anishchenko ${ }^{b}$, and M. I. Gladyshev ${ }^{b, c}$ \\ ${ }^{a}$ Institute of Systematics and Ecology of Animals, Siberian Branch, Russian Academy of Sciences, \\ ul. Frunze 11, Novosibirsk, 630091 Russia \\ ${ }^{b}$ Institute of Biophysics, Siberian Branch, Russian Academy of Sciences, Akademgorodok, Krasnoyarsk, 660036 Russia \\ ${ }^{c}$ Siberian Federal University, pr. Svobody 79, Krasnoyarsk, 660041 Russia \\ e-mail: popova-2012@yandex.ru \\ e-mail: hydrakr@rambler.ru \\ e-mail:glad@ibp.ru
}

Received September 13, 2015; in final form, October 05, 2015

\begin{abstract}
Long-term monitoring of the abundance and spatial distribution of 18 widespread species of Odonata has made it possible to assess their contribution to the export of aquatic resources that entered the Barabinsk forest-steppe ecosystem. The annual emergence of Ordonata varies from 0.8 to $4.9 \mathrm{~g} / \mathrm{m}^{2}$ of the land area and from 2.3 to $13.3 \mathrm{~g} / \mathrm{m}^{2}$ of the water area, which is $4-5$ times larger than that in Diptera. The total flux of organic matter from water to terrestrial ecosystems remains relatively stable (sixfold interannual variability) irrespective of large interannual variations in the abundance of separate species (e.g., 42-fold interannual variability in Libellula quadrimaculata). The metal content was determined in nine Odonata species. Export of metals by odonates decreases in the series $\mathrm{K}>\mathrm{Na}>\mathrm{Mg}>\mathrm{Ca}>\mathrm{Fe}>\mathrm{Zn}>\mathrm{Cu}>\mathrm{Mn}>\mathrm{Pb}>\mathrm{Ni}>\mathrm{Cr}>\mathrm{Cd}$. Therefore, odonates appear to be quantitatively and qualitatively important providers of aquatic resources to the forest-steppe landscape of Western Siberia.
\end{abstract}

Keywords: Odonata, long-term ecological monitoring, emergence, abundance, biomass, metals, Barabinsk forest steppe, Western Siberia

DOI: $10.1134 /$ S1995425516040090

The principle of the existence of any ecosystem is based on the permanent movement of fluxes of organic matter, energy, and information in trophic chains (Lekyavichus, 1986; Alimov, 2000). The transfer of matter along the gradient of an abiogenic runoff, i.e., from terrestrial to water ecosystems, has been studied most deeply, while its transfer against the gradient of the runoff has been studied rather fragmentarily (Gratton and Vander Zanden, 2009). Amphibiotic insects (whose preimaginal phases develop in water, while imagoes have a terrestrial mode of life) are one of the main biogenic factors of the return of many chemical elements from topographic lowlands (water bodies) to plakor areas (Baxter et al., 2005; Ballinger and Lake, 2006; Gratton and Vander Zanden, 2009). In some landscapes, the export of aquatic resources during the emergence of amphibiont insects may be comparable to the productivity of terrestrial insects or even be higher (Gratton and Vander Zanden, 2009).

Although a conceptual model generalizing all reliable data on the flux of aquatic resources via the emergence of amphibiotic insects has been proposed quite recently (Gratton and Vander Zanden, 2009), it has a number of limitations: (1) it is not intended for making predictions with respect to specific areas or regions; (2) the calculated mean values of dispersion of aquatic insects from the shore are underestimated, being no more than $100 \mathrm{~m}$; and (3)F the basic volume of data was obtained from watercourses. According to this generalization, Diptera constitute $60-99 \%$ of the emerging biomass, followed by Ephemeroptera, Plecoptera, and Trichoptera in decreasing order, and Odonata ranks last (Gratton and Vander Zanden, 2009).

At the same time, due to a number of biological and ecological features, odonates are of substantial interest for productive ecology. First, over the period of larval development in a water body (from several months to several years), a significant reserve of organic matter in terms of amount and quality accumulates in the body of larvae. Second, the morphophysiological organization and mode of life of odonate imagoes determine their high motility: they can disperse tens of kilometers (some species even hundreds of kilometers) from native water bodies (Haritonov and Popova, $2011 \mathrm{a}, \mathrm{b}$ ), thereby contributing to 
dispersion of organic matter over a large land area. Third, Odonata colonize almost all types of freshwater bodies, and a greater portion of species inhabit temporary water bodies, such as ditches, puddles, and bogs (Clark and Samways, 1996; Harabis and Dolny, 2010; Haritonov and Popova, 2011 a). Thus, in some landscapes, e.g., in steppes, where a greater part of water bodies are temporary puddles and bogginess, and in areas with high fluctuations of the level of water content (e.g., Barabinsk forest steppe), odonates may also be a quantitatively important group of amphibiotic insects. Therefore, the main purpose of our research was to assess the export of water ecosystem productivity by odonates to terrestrial cenoses in a specific landscape, namely, the Barabinsk forest steppe in the southeast of Western Siberia.

In addition to the export of organic carbon, representing a source of food for terrestrial consumers, the biomass that is exported from water ecosystems also contains other biogenic and toxic elements, e.g., heavy metals (HMs). HMs may accumulate in higher links of trophic chains, thereby posing potential danger for human health (Zhou et al., 1998; Gladyshev et al., 2009). The content of HMs is generally determined in amphibiotic insect larvae to monitor the water quality (Nummelin et al., 2007; Lavilla et al., 2010; Corbi and Froehlich, 2010; Corbi et al., 2011); however, there are limited data on HMs (Scheuhammer et al., 1997; Nummelin et al., 2007; Boron and Miroslawski, 2009; Burghelea et al., 2011). There are single studies that estimate export of metals, including nonessential metals, by amphibiotic insects, including odonates, to the land area (Currie et al., 1997). Therefore, the second purpose of our research was to measure the metal content in odonate imagoes and assess the export of metals by emerging odonates in a specific landscape. In our work, we did not seek to reveal the largest possible number of chemical elements and focused only on elements that are the most significant for the ecosystem, both from the general biological and toxicological points of view: $\mathrm{K}, \mathrm{Na}, \mathrm{Ca}, \mathrm{Mg}, \mathrm{Fe}, \mathrm{Cu}, \mathrm{Zn}, \mathrm{Mn}, \mathrm{Ni}$, $\mathrm{Cr}, \mathrm{Pb}$, and $\mathrm{Cd}$.

\section{MATERIALS AND METHODS}

Study Site. The studies were carried out in the southeast of Western Siberia, in the Barabinsk forest steppe, and in the basin of Lake Chana. The climate of the region is continental. The average temperature of the coldest month, i.e., January, is about $-20^{\circ} \mathrm{C}$, and the average temperature of the hottest month, i.e., July, is over $+18^{\circ} \mathrm{C}$. The frostless vegetation period is short, being 112 days, on average. The annual amount of precipitation is about $350 \mathrm{~mm}$; the relative air humidity is about $50-60 \%$. The rainiest month is July. The average annual wind velocity is about $5 \mathrm{~m} / \mathrm{s}$. The annual radiation is about $4000 \mathrm{MJ} / \mathrm{m}^{2}$ (Prirodnye..., 1963). The plain landscapes alternate with ridges and islets occupied by birch and birch-aspen forests with the undergrowth of bird cherry, brier, and other bushes. A greater part of the area is presented by a water-meadow-solonchak forest steppe, plowlands, and fallows. The Barabinsk forest steppe is the most depressed (so-called Chanovsk depression) and, accordingly, boggiest area in the forest steppe of Western Siberia and is distinguished by a high water-reserve level (30\% of the total area) and an unstable water regime (Prirodnye..., 1963).

The investigated plot is in Novosibirsk oblast $\left(54^{\circ} 32^{\prime}-54^{\circ} 39^{\prime} \mathrm{N}\right.$ and $\left.78^{\circ} 06^{\prime}-78^{\circ} 19^{\prime} \mathrm{E}\right)$, occupies the area of $272 \mathrm{~km}^{2}$, and is adjacent to the northeastern shore of Lake Malye Chany. The areas of different biotopes were calculated using satellite images in the Image 2010 Terra Metrics system, as well as 1-km scale maps and aerial photographs, and we also measured distances and angles directly in situ. As a result, it was established that the water-covered area-lakes, rivers, ponds, ditches, puddles, and bogs (including reed beds)-is $82 \mathrm{~km}^{2}$, of which only $69 \mathrm{~km}^{2}$ serve as a habitat for odonate larvae (further referred to as an odonatogenic water area). Odonate larvae are absent or their number is very low outside the odonatogenic water area, namely, in bitter lakes $\left(2 \mathrm{~km}^{2}\right)$ and water body sites without aquatic vegetation $\left(11 \mathrm{~km}^{2}\right)$ (Popova and Haritonov, 2012). Within the land area $\left(190 \mathrm{~km}^{2}\right)$, we selected seven biotopes, in which quantitative samples of imagoes were regularly performed: (1) wet lowland meadows $\left(87 \mathrm{~km}^{2}\right),(2)$ steppe meadows and fallows $\left(61 \mathrm{~km}^{2}\right)$, (3) tillage $\left(19 \mathrm{~km}^{2}\right)$, (4) birch and birchaspen groves $\left(8 \mathrm{~km}^{2}\right),(5)$ shrubs $\left(11 \mathrm{~km}^{2}\right),(6)$ shelterbelts $\left(3.5 \mathrm{~km}^{2}\right)$, and $(7)$ earth roads $\left(0.5 \mathrm{~km}^{2}\right)$.

Object of Research. The Barabinsk forest steppe is inhabited by 42 of the 68 odonate species generally known for the forest steppe of Western Siberia (Popova, 2007). To calculate products exported by odonates to the terrestrial ecosystems under study, we sampled 18 mass and middle-abundance species, which constitute $95-98 \%$ of both the abundance and biomass of odonates: suborder Zigopter-Coenagrion lunulatum (Charpentier, 1840), C. armatum (Charpentier, 1840), C. pulchellum (V.d. Linden, 1823), Enallagma cyathigerum (Charpentier, 1840), Erythromma najas (Hansemann, 1823), Lestes dryas Kirby, 1890, L. sponsa (Hansemann, 1823), L. virens (Charpentier, 1825), and Sympecma paedisca (Brauer, 1877); suborder Anisoptera-A, mixta Latreille, 1805, Aeshnt serrata Hagen, 1856, Leucorrhinia pectoralis (Charpentier, 1825), L. rubicunda (Linnaeus, 1758), Libellula quadrimaculata Linnaeus, 1758, Sympetrum danae (Sulzer, 1776), S. flaveolum (Linnaeus, 1758), S. sanguineum (Müller, 1764), and S. vulgatum (Linnaeus, 1758).

Quantitative Samples of Imagoes and Their Methods. In total, we performed 16721 quantitative samples in the land area over the period of 31 years from 1980 to 2010 , in which 614120 odonate imagoes were recorded. The counts were performed every year 
throughout the entire flying period of odonates, i.e., from May to October. There is a brief description of four methods of imago sampling that we applied and that are generally accepted in the population ecology of insects, including odonates (Kozhanchikov, 1961; Paliy, 1970; Popova and Haritonov, 2012, 2014; Corbet 1952, 1999; Parr, 1972; Conrad et al., 1999; Bried and Ervin, 2006).

Capture-Mark-Recapture. This sampling method is the main one, since it provides the most reliable results on the density of odonate population and is applicable to all investigated species (Popova and Haritonov, 2010, 2014; Corbet, 1952; Parr, 1972). On the sampling site with certain area $a$ (from 2000 to $15000 \mathrm{~m}^{2}$, depending on the motility of the species), odonate imago individuals in the number of $M$ were caught for several hours (usually in the morning) using an air net; each individual was marked with red waterresistant paint directly after capture, followed by its immediate release. On the next day, $n$ individuals were repeatedly caught, with $m$ previously marked individuals being present among them. The abundance of $N$ (individuals $/ \mathrm{m}^{2}$ ) was calculated by formula:

$$
N=[M \times(n+1) /(m+1)] / a
$$

Belt Transect (Route). This method is generally used for recording odonates from suborder Anisoptera and represents visual sampling on a belt with a predetermined length and a predetermined width. During sunny weather without strong winds, the observer goes along the belt on foot or by transport with a velocity of about $4 \mathrm{~km} / \mathrm{h}$ and counts all odonates that fly up or cross the sampling belt of odonates (species and number of individuals) by recording the information on a voice recorder. In our research, the transects almost completely coincided with earth roads and also crossed all the biotopes under study. A total of eight transects were used, with a length from 1375 to $5750 \mathrm{~m}$ and a width of $2 \mathrm{~m}$ each. Accordingly, the maximum area of the sampling belt was $5750 \times 2 \mathrm{~m}=11500 \mathrm{~m}^{2}$. Samples were taken on the transects every two to ten days throughout the season. The results of sampling on transects and counts based on marking and recapture were rather similar (Haritonov and Popova, 2011a).

Entomological Sweep Netting. This method is generally applied for recording odonates of suborder Zygoptera. While moving forward on the site, the observer makes one sweep a net once per step. Provided that the diameter of the net ring was $30 \mathrm{~cm}$, every 100 sweeps covered the cutting of $30 \mathrm{~m}^{2}$. The number of the collected individuals was multiplied by 2 , since simultaneous calculations established that the net captured no more than a half of individuals present on the site being cut, while about a half of them managed to fly away or dispersed aside, being knocked down by the net or grass stalks.
Capture during Timed Fifteen-Minute Intervals. Air-net based insect capture during a certain time interval is one of the standard methods to determine the relative abundance of insects (Paliy, 1970). The method can be applied for recording all Odonata. We generally used it for studying the biotopical confinement of species and the seasonal and diurnal dynamics of their abundance. Odonates were caught with a net on a site of about $500 \mathrm{~m}^{2}$ for 15 minutes. While moving slowly along the perimeter of the site and then along and across the site, the observer carefully examined the grass stand and the space above it and methodically and sequentially caught all detected damselflies (both sitting and flying ones) and put them into a closing vessel.

Selecting the time and place for sampling took into account the features of odonate life activity: response to weather conditions, diurnal and seasonal activity, biotopical preferences, and flying capabilities. All sampling sites were more or less evenly distributed over the seven main biotopes in the area under study. The counts based on capture-mark-recapture methods and entomological cutting and capture during timed intervals were made on 74 sampling sites 312 times for each of them per season.

Estimating the abundance of odonates involved all four methods of sampling, since each of them has its own taxonomic, biotopical, and functional specifics and is different in the accuracy of final results and in use efficiency.

To calculate the wet weight, 30-70 living juvenile individuals (males and females) per individual were weighed and the average wet weight with an accuracy of $\pm 1-20 \mathrm{mg}$ was determined. To calculate the dry weight, the same insects were dried in a drying cabinet at a temperature of $80^{\circ} \mathrm{C}$ for $24 \mathrm{~h}$, followed by their weighing with an accuracy of $\pm 0-6 \mathrm{mg}$.

After recording and identification, most of the caught individuals were released back to the natural environment and a small number of individuals were used for morphometry, weighing, and biochemical analysis.

The period of mass emergence (PME, days/year) of each species was determined by monitoring the abundance of imagoes on the sampling sites located in the vicinity of the near-shore area that is overgrown with helophytes, hygrohelophytes (water edge plants), and hygrophytes and serves as a zone for odonate emergence. In addition, we used the above-described method of imago capture for $15 \mathrm{~min}$. By the beginning of the PME, we assumed the date when the species was presented in a number of no less than three individuals in sampling and its relative abundance reached $5 \%$ of the total number of individuals in sampling (Pesenko, 1982), while by the end of the PME we assumed the date when the species was presented in a number of less than three individuals in sampling, and its relative abundance was less than 5\%, respectively. Using the 
data of all the near-shore sites, we calculated the average duration of the PME for each species and for each year. The long-term annual average duration of the PME over the period from 1980 to 2010 was then calculated.

The lifetime of imagoes (LTI) of each species was measured by two methods. (1) Imago mark, which makes it possible to establish the ecological LTI (Gavrilov and Gavrilova, 1991). Individual and dataspecific marks were put on the wings of young imagoes soon after their emergence, but not before cuticle hardening, and the marked individuals were then monitored over the period of the flying season during local and route counts (Pajunen 1962; Ubukata, 1981; Bennett and Mill 1995). (2) Content in precipitation, which makes it possible to determine the physiological (species) LTI (Gavrilov and Gavrilova, 1991). The newly emerged imagoes were placed into a $1 \times 1 \times 1 \mathrm{~m}$ cage covered with a fine-meshed screen. Plant branches were attached to the cage bottom as roosts for odonates. The cages with odonates were located in a well-ventilated room under natural lighting. The odonates were fed with different insects and spiders once a day. For each individual, the time interval from the date of its emergence to the date of its death in the cage was assumed to be its lifetime. The LTI values obtained by these two methods were rather similar.

\section{Calculation of Imago Emergence}

The quantitative estimate of the emergence of odonate imagoes included a calculation of the abundance, biomass, and Haritonov's coefficient. All calculations were first made separately for each species and for each year (season) on the basis of all the performed quantitative samples. The number of samples per year varied from 394 to 850 . All the above-given calculations estimate the emergence of odonate imagoes per unit of the land area under study. To estimate the emergence per unit of the water area being studied, we used the coefficient equal to the ratio between the land area and the odonatogenic water area: $190 \mathrm{~km}^{2} / 69 \mathrm{~km}^{2}=2.75$.

The average annual abundance of each species, $N_{Y S}$ $\left(1 \times 10^{6}\right.$ individuals $/ \mathrm{km}^{2}$ or individuals $\left./ \mathrm{m}^{2}\right)$, within the entire investigated area was calculated by the following formula:

$$
N_{Y S}=\sum_{i=1}^{7} N_{S i} A_{i} / \sum_{i=1}^{7} A_{i} .
$$

That is, the average abundance of species $S$ within biotope $i$ (from the total of seven biotopes) was first calculated; for this purpose, the average annual density of the population in the biotope, $N_{\mathrm{Si}}\left(1 \times 10^{6}\right.$ individuals $/ \mathrm{km}^{2}=$ individuals $/ \mathrm{m}^{2}$ ), was multiplied by the biotope area $\mathrm{A}_{i}\left(\mathrm{~km}^{2}\right.$ or $\left.\mathrm{m}^{2}\right)$; the abundances of all seven biotopes were then summed up and this sum was divided into the entire area under study, $\sum_{i=1}^{7} A_{i}=$ $190 \mathrm{~km}^{2}$.

The total average annual abundance, $N_{\mathrm{Y}}\left(1 \times 10^{6}\right.$ individuals $/ \mathrm{km}^{2}=$ individuals $/ \mathrm{m}^{2}$ ), made up the sum of average annual abundances, $N_{\text {YS }}$, of all 18 odonate species.

The average annual abundance reflects only a portion of the entire number of odonates that emerged from water bodies, since the period of emergence is elongated for several weeks and even months and generally exceeds the average duration of individual imago life. As a result, several sets (fluxes) of imagoes of the same species consistently pass through the same territory during the season.

Therefore, the annual emergence of the species that is based on its abundance, i.e., on the number of individuals of the species of odonates that emerged in the land area under study over the whole year, $E_{S}$ (individuals $/\left(\mathrm{m}^{2}\right.$ year $)$ ), was calculated by the following formula:

$$
E_{S}=N_{Y S} R_{S}
$$

where $N_{Y S}$ is the average annual abundance of the species, $R_{\mathrm{S}}$ (year ${ }^{-1}$ ) is the coefficient of renewability of fluxes of the species imago. This coefficient was introduced in odonate ecology by A. Yu. Haritonov and was calculated by the following formula:

$$
R_{\mathrm{S}}=\mathrm{D}_{\mathrm{S}} / \mathrm{L}_{\mathrm{S}}
$$

where $D_{S}$ is the duration of the period of mass emergence of species $S$ per year (days/year) and $L_{S}$ is the lifetime of imago (days) of the species under consideration $(\mathrm{S})$; their calculations are given above.

The annual total emergence of the odonate population, $\mathrm{E}_{\mathrm{Y}}$ (individuals $/\left(\mathrm{m}^{2}\right.$ year $)$ ), makes up the sum of annual emergences $\mathrm{E}_{\mathrm{S}}$ of all 18 species.

The annual total emergence biomass of the odonate population, $\mathrm{B}_{\mathrm{Y}} \mathrm{g} /\left(\mathrm{m}^{2}\right.$ year $)$ or $\mathrm{t} /\left(\mathrm{km}^{2}\right.$ year $)$, was calculated by the following formula:

$$
B_{Y}=\sum_{S=1}^{18} E_{S} B_{S}
$$

where $E_{S}$ is the annual emergence and $B_{S}$ is the average biomass of species $\mathrm{S}$.

\section{Determination of Metal Content in Odonate Imagoes}

To determine the total content of metals, preliminarily dried samples were ground in an agate mortar and then held at $105^{\circ} \mathrm{C}$ until they reached constant weight. The sample $(0.2-0.6 \mathrm{~g})$ was mineralized by evaporating it in a mixture of nitric and perchloric acids $(1: 1)$ and reduced to $15 \mathrm{~mL}$ by distillation. To determine $\mathrm{Ca}$ and $\mathrm{Mg}$, the samples were diluted in the 
Table 1. Odonate emergence in the investigated land area, Barabinsk Steppe, Western Siberia

\begin{tabular}{|c|c|c|c|c|c|c|}
\hline \multirow[t]{2}{*}{ Species } & \multicolumn{2}{|c|}{$\begin{array}{c}\text { Abundance, } \\
\text { individuals } /\left(\mathrm{m}^{2} \text { year }\right)\end{array}$} & \multicolumn{2}{|c|}{$\begin{array}{l}\text { Wet biomass, } \\
\mathrm{mg} /\left(\mathrm{m}^{2} \text { year }\right)\end{array}$} & \multicolumn{2}{|c|}{$\begin{array}{l}\text { Dry biomass, } \\
\mathrm{mg} /\left(\mathrm{m}^{2} \text { year }\right)\end{array}$} \\
\hline & $M \pm m$ & $\min -\max$ & $M \pm m$ & $\min -\max$ & $M \pm m$ & $\min -\max$ \\
\hline Coenagrion armatum & $1.55 \pm 0.16$ & $0.53-3.96$ & $47 \pm 5$ & $16-120$ & $14 \pm 1$ & $5-36$ \\
\hline Coenagrion pulchellum & $2.86 \pm 0.7$ & $0.40-20.30$ & $91 \pm 25$ & $13-650$ & $32 \pm 9$ & $4-220$ \\
\hline Coenagrion lunulatum & $1.14 \pm 0.08$ & $0.40-2.12$ & $34 \pm 2$ & $12-64$ & $10 \pm 1$ & $4-19$ \\
\hline Enallagma cyathigerum & $5.79 \pm 0.85$ & $0.62-26.83$ & $197 \pm 29$ & $21-912$ & $67 \pm 10$ & $7-322$ \\
\hline Erythromma najas & $1.35 \pm 0.23$ & $0.35-7.36$ & $6 \pm 1$ & $2-31$ & $19 \pm 3$ & $5-103$ \\
\hline Lestes dryas & $0.64 \pm 0.06$ & $0.16-1.63$ & $30 \pm 3$ & $8-7$ & $79 \pm 1$ & $2-23$ \\
\hline Lestes sponsa & $3.00 \pm 0.17$ & $1.00-5.30$ & $129 \pm 7$ & $43-228$ & $39 \pm 2$ & $13-69$ \\
\hline Lestes virens & $0.63 \pm 0.06$ & $0.24-1.45$ & $18 \pm 2$ & $7-42$ & $6 \pm 1$ & $2-13$ \\
\hline Sympecma paedisca & $1.87 \pm 0.09$ & $0.46-2.66$ & $58 \pm 3$ & $14-83$ & $19 \pm 1$ & $5-27$ \\
\hline Aeshna mixta & $0.12 \pm 0.01$ & $52 \pm 4$ & $13-88$ & $16 \pm 1$ & $4-28$ & $0.03-0.20$ \\
\hline Aeshna serrata & $0.15 \pm 0.01$ & $0.08-0.29$ & $119 \pm 7$ & $58-222$ & $37 \pm 2$ & $18-69$ \\
\hline Leucorrhinia pectoralis & $0.45 \pm 0.04$ & $0.10-0.87$ & $89 \pm 7$ & $21-170$ & $27 \pm 2$ & $6-53$ \\
\hline Leucorrhinia rubicunda & $0.46 \pm 0.05$ & $0.09-1.20$ & $86 \pm 10$ & $16-224$ & $26 \pm 3$ & $5-69$ \\
\hline Libellula quadrimaculata & $0.12-5.00$ & $356 \pm 59$ & $38-1600$ & $95 \pm 16$ & $10-430$ & $1.12 \pm 0.18$ \\
\hline Sympetrum danae & $1.20 \pm 0.07$ & $0.50-2.12$ & $108 \pm 7$ & $45-191$ & $32 \pm 2$ & $13-57$ \\
\hline Sympetrum flaveolum & $1.94 \pm 0.17$ & $0.38-3.88$ & $204 \pm 18$ & $40-407$ & $64 \pm 6$ & $12-128$ \\
\hline Sympetrum sanguineum & $0.22 \pm 0.02$ & $0.03-0.56$ & $25 \pm 3$ & $3-64$ & $8 \pm 1$ & $1-20$ \\
\hline Sympetrum vulgatum & $0.68-7.22$ & $447 \pm 32$ & $103-1090$ & $130 \pm 9$ & $30-318$ & $2.96 \pm 0.21$ \\
\hline Total & $27.47 \pm 2.09$ & $9.99-77.59$ & $2147 \pm 132$ & $843-4856$ & $650 \pm 40$ & $252-1493$ \\
\hline
\end{tabular}

Note: $M$, mean value for 31 years; $m$, standard error of mean; min, minimum value; and max, maximum value.

ratio of $1 \mathrm{~mL}$ of $\mathrm{LaCl}_{3}$ solution (the mass concentration of La was $20 \mathrm{~g} / \mathrm{L}$ ) and $8 \mathrm{~mL}$ of distilled water per $1 \mathrm{~mL}$ of ashed sample. The calibration standards also contained the necessary addition of $\mathrm{LaCl}_{3}$.

Concentrations of $\mathrm{Na}$ and $\mathrm{K}$ were determined on a FLAPHO-4 flame photometer (Carl Zeiss, Jena) in the propane-air flame (GOST 30503-97 and GOST 30504-97). Ca and $\mathrm{Mg}$ were determined by the atomic absorption method in the air-acetylene flame on a Solaar M5 spectrophotometer (Thermo Electron Corp., United States) (GOST 26570-95 and GOST 30502-97) and $\mathrm{Fe}, \mathrm{Mn}, \mathrm{Zn}, \mathrm{Cu}, \mathrm{Cr}, \mathrm{Ni}, \mathrm{Cd}$, and $\mathrm{Pb}$ were determined on an AAS Kvant-2A photometer (GOST 30692-2000). The detection limits (mg/L) were 0.1 for $\mathrm{Na}$ and $\mathrm{K}, 0.001$ for $\mathrm{Ca}, 0.0005$ for $\mathrm{Mg}$, 0.003 for $\mathrm{Fe}, \mathrm{Ni}, \mathrm{Pb}$, and $\mathrm{Co}, 0.002$ for $\mathrm{Cr}, 0.0006$ for $\mathrm{Cu}, 0.001$ for $\mathrm{Mn}$, and 0.0003 for $\mathrm{Zn}$ and $\mathrm{Cd}$. State standard samples (STSs) (OAO Ural'skii Zavod Khimreaktivov (Ural Reagent Plant)) were used as reference samples for the elements being analyzed. The samples were analyzed based on their comparison with each other and, respectively, included 20 individuals of $S$. paedisca, 4 individuals of $L$. rubicunda, 54 individuals of E. cyathigerum, 33 individuals of E. najas, 4 individuals of $L$. quadrimaculata, 2 individuals of A. serrata, 7 individuals of $S$. vulgatum, and 10 individ- uals of $S$. flaveolum. The metal content in odonates of L. Dryas species was revealed in two samples consisting of 45 males and 40 females.

\section{Statistical Analysis}

To calculate the basic statistical parameters, we used the Statistica software package, version 9 (StatSoft, Inc., Tulsa, OK, United States).

\section{RESULTS}

Over the entire period of investigation, i.e., from 1980 to 2010 , the total average annual abundance of the odonate population, $N_{\mathrm{Y}}$, varied in a rather wide range, being from 3.0 (in 2010) to 23.2 samples $/ \mathrm{m}^{2}$ (in 1988), at the average value being 8.3 individuals $/ \mathrm{m}^{2}$.

Tables 1-2 provide long-term annual average values on odonate emergence, $E_{\mathrm{Y}}$, expressed through abundance and biomass. Three values are well correlated with the average annual abundance, $N_{\mathrm{Y}}$, and, therefore, the minimum and maximum values of emergence that are given in the tables correspond to 2010 and 1988, respectively.

One can distinguish the following ecological trends of the investigated species and their long-term annual 
Table 2. Odonate emergence from the odonatogenic water area, Barabinsk forest steppe, Western Siberia

\begin{tabular}{|c|c|c|c|c|c|c|}
\hline \multirow[t]{2}{*}{ Species } & \multicolumn{2}{|c|}{$\begin{array}{c}\text { Abundance, } \\
\text { individuals } /\left(\mathrm{m}^{2} \text { year }\right)\end{array}$} & \multicolumn{2}{|c|}{$\begin{array}{l}\text { Wet biomass, } \\
\mathrm{mg} /\left(\mathrm{m}^{2} \text { year }\right)\end{array}$} & \multicolumn{2}{|c|}{$\begin{array}{l}\text { Dry biomass, } \\
\mathrm{mg} /\left(\mathrm{m}^{2} \text { year }\right)\end{array}$} \\
\hline & $M \pm m$ & $\min -\max$ & $M \pm m$ & $\min -\max$ & $M \pm m$ & $\min -\max$ \\
\hline Coenagrion armatum & $4.27 \pm 0.44$ & $1.45-10.86$ & $128 \pm 13$ & $43-326$ & $38 \pm 4$ & $13-98$ \\
\hline Coenagrion lunulatum & $7.85 \pm 2.15$ & $1.14-55.70$ & $252 \pm 69$ & $36-1780$ & $86 \pm 24$ & $12-610$ \\
\hline Coenagrion pulchellum & $3.13 \pm 0.22$ & $1.10-5.82$ & $94 \pm 7$ & $33-174$ & $28 \pm 2$ & $10-52$ \\
\hline Enallagma cyathigerum & $15.91 \pm 2.33$ & $1.69-73.70$ & $541 \pm 79$ & $57-2506$ & $191 \pm 28$ & $20-884$ \\
\hline Erythromma najas & $3,70 \pm 0.63$ & $0.96-20.23$ & $156 \pm 26$ & $40-850$ & $52 \pm 9$ & $13-283$ \\
\hline Lestes dryas & $1.76 \pm 0.17$ & $0.45-4.48$ & $83 \pm 8$ & $21-210$ & $25 \pm 2$ & $6-63$ \\
\hline Lestes sponsa & $8.25 \pm 0.47$ & $2.75-14.56$ & $355 \pm 20$ & $118-626$ & $107 \pm 6$ & $36-189$ \\
\hline Lestes virens & $1.74 \pm 0.16$ & $0.66-3.98$ & $51 \pm 5$ & $19-116$ & $16 \pm 1$ & $6-36$ \\
\hline Sympecma paedisca & $5.13 \pm 0.26$ & $1.27-7.32$ & $159 \pm 8$ & $39-227$ & $51 \pm 3$ & $13-73$ \\
\hline Aeshna mixta & $0.32 \pm 0.02$ & $0.08-0.55$ & $142 \pm 10$ & $35-243$ & $45 \pm 3$ & $11-76$ \\
\hline Aeshna serrata & $0.43 \pm 0.03$ & $0.21-0.79$ & $329 \pm 19$ & $165-611$ & $103 \pm 6$ & $52-191$ \\
\hline Leucorrhinia pectoralis & $1.24 \pm 0.10$ & $0.29-2.40$ & $246 \pm 20$ & $58-480$ & $76 \pm 6$ & $18-150$ \\
\hline Leucorrhinia rubicunda & $1.28 \pm 0.14$ & $0.25-3.31$ & $237 \pm 27$ & $46-616$ & $73 \pm 8$ & $14-189$ \\
\hline Libellula quadrimaculata & $3.09 \pm 0.51$ & $0.33-13.90$ & $982 \pm 163$ & $110-4410$ & $258 \pm 43$ & $30-1180$ \\
\hline Sympetrum danae & $3.31 \pm 0.21$ & $1.38-5.85$ & $298 \pm 18$ & $124-526$ & $89 \pm 6$ & $37-158$ \\
\hline Sympetrum flaveolum & $5.35 \pm 0.46$ & $1.05-10.68$ & $562 \pm 49$ & $110-1122$ & $176 \pm 15$ & $35-352$ \\
\hline Sympetrum sanguineum & $0.60 \pm 0.07$ & $0.07-1.55$ & $69 \pm 8$ & $8-176$ & $21 \pm 2$ & $3-54$ \\
\hline Sympetrum vulgatum & $8.15 \pm 0.59$ & $1.88-19.87$ & $1230 \pm 89$ & $283-3001$ & $358 \pm 26$ & $83-875$ \\
\hline Total & $75.50 \pm 5.74$ & $27.53-213.28$ & $5912 \pm 363$ & 2321-13347 & $1793 \pm 110$ & 705-4108 \\
\hline
\end{tabular}

Note: $M$, mean value for 31 years; $m$, standard error of mean; min, minimum value; and max, maximum value.

average values. The lifetime $\mathrm{L}_{\mathrm{S}}$ varied from 10 (Coenagrion armatum, $C$. lunulatum, and $C$. pulchellum) to 20 days (Aeshna mixta and $A$. serrata); the duration of the period of mass emergence, $\mathrm{D}_{\mathrm{S}}$, varied from 30 (Coenagrion sp. and Leucorrhinia sp.) to 60 days (Aeshna spp., Sympetrum danae, S. flaveolum, Enallagma cyathigerum, and Sympecma paedisca). The value of Haritonov's size coefficient, $R_{\mathrm{S}}$, varied from 2.5 (Leucorrhinia pectoralis and L. rubicunda) to 4 (E. cyathigerum, S. paedisca, and S. flaveolum), which, on average, corresponds to the number of emergence peaks per year. The average wet weight per individual varied from 29 (Lestes virens) to $47 \mathrm{mg}$ (Lestes dryas) in species of suborder Zygoptera and from 90 (S. danae) to $771 \mathrm{mg}$ (A. serrata) in Anisoptera. The average dry weight of one individual varied from 9 to $14 \mathrm{mg}$ in species of suborder Zygoptera and from 27 to $241 \mathrm{mg}$ in Anisoptera, provided that the species set was the same. In all species the moisture content in bodies was rather similar, being on average, $69.0 \pm 0.5 \%$; therefore, their dry weight was well correlated with their wet weight. The quantitative share of species (the percentage of species individuals of the total number of individuals of all species) varied from $0.5 \%$ (A. mixta) to $19.4 \%$ (E. cyathigerum); the mass share (the weight of species individuals of the total weight of individuals of all spe- cies) varied from $0.9 \%$ (L. virens) to $21.3 \%$ (S. vulgatum) both in wet and dry weight.

Eleven of the 18 species had a rather high abundance (the annual number of individuals that emerged in the land area), and their total long-term annual average quantitative share was $90 \%$ of the long-term annual average abundance of all the 18 species: Enallagma cyathigerum (19.4\%), Lestes sponsa (11.4\%), Sympetrum vulgatum (11.3\%), Coenagrion lunulatum (8.3\%), Sympecma paedisca (7.8\%), S. flaveolum (7.4\%), C. armatum (6.0\%), S. danae (4.9\%), Coenagrion pulchellum (4.8\%), Erythromma najas $(4.5 \%)$, and Libellula quadrimaculata (3.8\%). Of these 11 species, seven species (total share $62.2 \%$ ) belong to suborder Zygoptera, and four species (total share 27.4\%) belong to suborder Anisoptera (L. quadrimaculata and three species of the genus Sympetrum). The other seven of the 18 species had a low abundance (their individual shares are less than $3 \%$ ) and were $10 \%$ in total.

Eleven of the 18 species had a rather high biomass (annual biomass of individuals that emerged in the land area), and their total long-term annual average share was $87.2 \%$ of the biomass of all 18 species: Sympetrum vulgatum (21.3\%), Libellula quadrimaculata (14.8\%), S. flaveolum (9.5\%), Enallagma cyathigerum 
(8.6\%), Lestes sponsa (6.3\%), Aeshna serrata (6.2\%), S. danae (5.5\%), Leucorrhinia pectoralis (4.4\%), Leucorrhinia rubicunda (4.1\%), Coenagrion lunulatum (3.5\%), and Sympecma paedisca (3\%). Of these 11 species, seven species (total share $65.8 \%$ ) belong to suborder Anisoptera and four species (total share 21.4\%) belong to suborder Zygoptera ( $C$. lunulatum, E. cyathigerum, L. sponsa, and S. paedisca). These 11 species provide about $87 \%$ of biomass export. The other seven of the 18 species had a low biomass (their individual shares were less than $3 \%$ ) and were $12.8 \%$ in total.

In nine odonate species belonging to two suborders, Anisoptera (five species) and Zygoptera (four species), we measured the content of 12 chemical elements and calculated their export to the land area; of these elements, eight $(\mathrm{Cr}, \mathrm{Mn}, \mathrm{Fe}, \mathrm{Ni}, \mathrm{Cu}, \mathrm{Zn}, \mathrm{Cd}$, and $\mathrm{Pb}$ ) belong to microelements, in particular, to heavy metals (HMs), and four ( $\mathrm{K}, \mathrm{Na}, \mathrm{Ca}$, and $\mathrm{Mg}$ ) belong to macroelements (MEs). All 12 investigated elements, except for lead and cadmium, belong to biologically essential elements. The content of metals in the investigated odonate imagoes (a total of ten samples were studied) is given in Table 3 . The concentration of $\mathrm{Co}$ in the investigated samples was below the analytical detection limit. On average, the content of $\mathrm{HMs}$ in nine Odonata species decreases in the $\mathrm{Fe}>\mathrm{Zn}$ $>\mathrm{Cu}>\mathrm{Mn}>\mathrm{Pb}>\mathrm{Ni}>\mathrm{Cr}>\mathrm{Cd}$ order, and the content of MEs decreases in the $\mathrm{K}>\mathrm{Na}>\mathrm{Mg}>\mathrm{Ca}$ order; the content of MEs in both odonate suborders and of HMs in suborder Anisoptera decreases in the same rows as in the whole order; in turn, the distribution of heavy metals in suborder Zygoptera is somewhat different: $\mathrm{Fe}>\mathrm{Zn}>\mathrm{Cu}>\mathrm{Mn}>\mathrm{Ni}>\mathrm{Cd}>\mathrm{Cr}$, with no $\mathrm{Pb}$ revealed. The content of elements varied between different species both qualitatively (a set of elements) and quantitatively (concentration of elements) (Table 3 ). In all nine investigated odonate species, we revealed all the four macroelements and four $(\mathrm{Fe}, \mathrm{Cu}$, $\mathrm{Zn}$, and $\mathrm{Mn}$ ) of the eight investigated heavy metals. Each species amounts to five ( $S$. paedisca) to seven (E. najas and L. quadrimaculata) HMs. Six of the 12 elements revealed in odonates have rather high concentrations in most of the investigated odonate species. Thus, four HMs were $99 \%$ of the total concentration of all the eight HMs for nine species: Fe $50 \%, \mathrm{Zn}$ $37 \%, \mathrm{Cu} 9 \%$, and $\mathrm{Mn} 3 \%$. Two MEs were $93 \%$ of the total concentration of four MEs for nine species: $\mathrm{K}$ $70 \%$ and $\mathrm{Na} 23 \%$.

The total content of all the investigated metals is approximately the same both in different odonate species and in different suborders (Table 3), while the content of separate elements varies rather significantly between species of the same suborder, family, and even genus (Table 3 ). Thus, $A$. serrata was characterized by the largest content of $\mathrm{Cu}, \mathrm{Zn}, \mathrm{Mn}, \mathrm{Ni}, \mathrm{Cd}$, and $\mathrm{Ca}, S$. paedisca by the largest content of Fe, S. flaveolum by the largest content of $\mathrm{Cr}$, and L. dryas and E. cyathigerum by the largest content of $\mathrm{K}, \mathrm{Na}$, and
Mg. Nickel was not revealed in L. rubicunda and $S$. flaveolum; however, we revealed $\mathrm{Pb}$ only in these species, with its content having an 18-fold variation: from 0.49 in $S$. flaveolum to $8.81 \mu \mathrm{g} / \mathrm{g}$ of dry weight in $L$. rubicunda. Cd was not found in $S$. paedisca and $S$. flaveolum. Finally, $\mathrm{Cr}$ was revealed only in $E$. najas, L. quadrimaculata, and S. flaveolum. Significant differences in the content of metals were found in two species belonging to the same genus Sympetrum: unlike $S$. flaveolum, $S$. vulgatum had no $\mathrm{Pb}$ and $\mathrm{Cr}$; however, the content of $\mathrm{Ni}$ and $\mathrm{Cd}$ was revealed in it, which is absent in $S$. flaveolum, and the content of $\mathrm{Cu}$ and $\mathrm{Mn}$ in $S$. vulgatum was twice as high as that in S. flaveolum.

The data on metal content and odonate emergence were used for calculating the export of metals (Tables 4,5$)$ to the land area and from the water area $\left(\mathrm{g} / \mathrm{m}^{2}\right)$. For this purpose, the metal content $(\mu \mathrm{g} / \mathrm{g}$ of dry weight) (Table 3 ) was multiplied by the value of dry biomass of odonates of the respective species $\left(\mathrm{g} /\left(\mathrm{m}^{2}\right.\right.$ year)) (Tables 1, 2). For 18 species, the export of HMs was 175.31 and the export of MEs was 10638.55 , the total of the revealed metals being $10813.86 \mu \mathrm{g} /\left(\mathrm{m}^{2}\right.$ year). Export of HMs by odonates decreases in the $\mathrm{Fe}>\mathrm{Zn}>\mathrm{Cu}>\mathrm{Mn}>\mathrm{Pb}>\mathrm{Ni}>\mathrm{Cr}>\mathrm{Cd}$ order, while export of MEs decreases in the $\mathrm{K}>\mathrm{Na}>\mathrm{Mg}>\mathrm{Ca}$ order. Among the nine investigated species, the maximum export of metals was recorded in representatives of suborder Anisoptera: $\mathrm{Cu}, \mathrm{Zn}, \mathrm{Mn}, \mathrm{K}$, and $\mathrm{Mg}$ in $S$. vulgatum, $\mathrm{Fe}, \mathrm{Ni}, \mathrm{Cd}, \mathrm{Na}$, and $\mathrm{Ca}$ in L. quadrimaculata, $\mathrm{Pb}$ in L. rubicunda, $\mathrm{Cr}$ in $S$. flaveolum, and $\mathrm{Cd}$ in $A$. serrata (Tables 4, 5). Among Zygoptera species, the species $E$. cyathigerum is the absolute leader with respect to export of metals, except for $\mathrm{Pb}$ and $\mathrm{Cr}$, which are absent in E. cyathigerum (Tables 4, 5).

\section{DISCUSSION}

Thirty-one-year studies of the seasonal and interannual dynamics of the abundance of odonate imagoes, as well as their spatial distribution and migration, have made it possible to estimate the export of biomass (organic matter) and metals from water bodies to the Prichanov area of the Barabinsk forest steppe by these insects. The emergence of the investigated odonate population was rather significant, reaching 27.5-213.3 individuals $/ 4 \mathrm{~m}^{2}$ of the water area per year. For comparison, the annual emergence of odonates from temporary water bodies of South Carolina (United States) was 0.8-8.4 (Leeper and Taylor, 1998) and 98 individuals per $1 \mathrm{~m}^{2}$ of the water area from miner rivers of Palawan Island (Philippines) (Freitag, 2004).

Biomass export from the unit water area by odonates was $2.3-13.3 \mathrm{~g} /\left(\mathrm{m}^{2}\right.$ year $)$ of wet weight and $0.7-$ $4.1 \mathrm{~g} /\left(\mathrm{m}^{2}\right.$ year $)$ of dry weight, which is $4-5$ times larger than that in representatives of Diptera: $1.25 \mathrm{~g} /\left(\mathrm{m}^{2}\right.$ year) of wet weight or $0.45 \mathrm{~g} /\left(\mathrm{m}^{2}\right.$ year $)$ of dry weight for mosquitos (Culicidae) (Gladyshev et al., 2011) and 


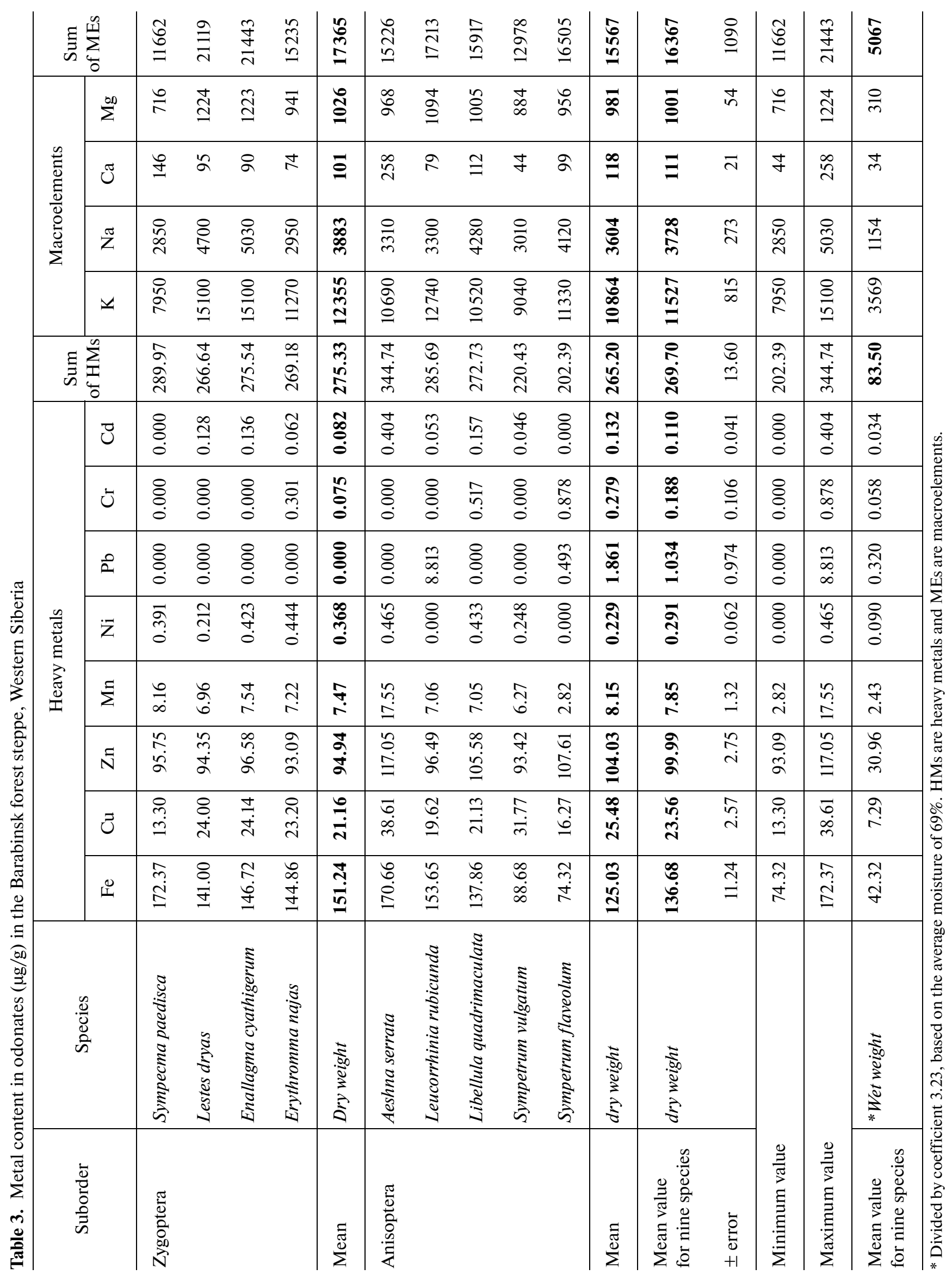

CONTEMPORARY PROBLEMS OF ECOLOGY Vol. 9 No. 42016 


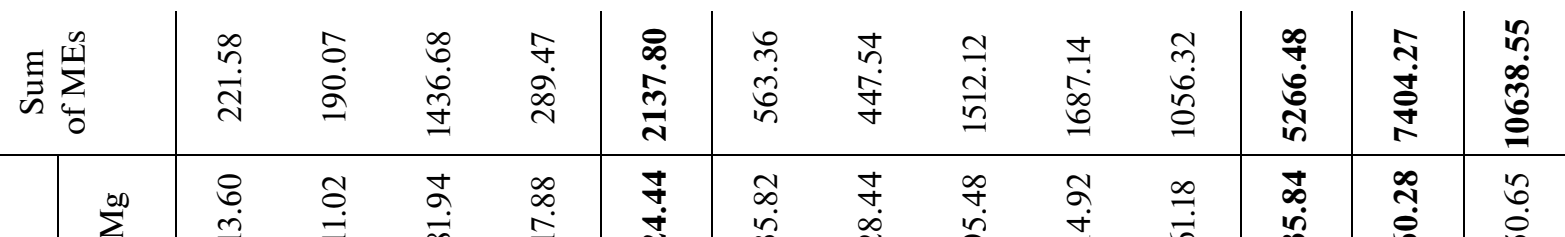

\begin{tabular}{|c|c|c|c|c|c|c|c|c|c|c|c|c|c|}
\hline$\sum^{\infty}$ & $\begin{array}{l}\stackrel{8}{0} \\
\stackrel{2}{2}\end{array}$ & 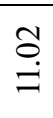 & $\frac{5}{\infty}$ & 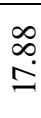 & $\begin{array}{l}\stackrel{J}{+} \\
\stackrel{\Xi}{\Xi}\end{array}$ & $\begin{array}{l}\tilde{D} \\
\dot{m} \\
\ddot{n}\end{array}$ & $\begin{array}{l}\underset{+}{+} \\
\underset{\sim}{\sim}\end{array}$ & $\begin{array}{l}\stackrel{\infty}{+} \\
\dot{a}\end{array}$ & $\begin{array}{l}\hat{\sigma} \\
\underset{J}{J}\end{array}$ & $\stackrel{\infty}{-1}$ & 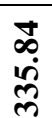 & 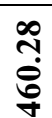 & $\begin{array}{l}n \\
0 \\
0 \\
6 \\
6\end{array}$ \\
\hline & $=$ & & $\stackrel{m}{\Omega}$ & & 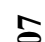 & in & $\stackrel{n}{n}$ & I & $\approx$ & I & 8 & 0 & \\
\hline
\end{tabular}

\begin{tabular}{|c|c|c|c|c|c|c|c|c|c|c|c|c|c|}
\hline$\tilde{U}$ & $\stackrel{\widehat{i}}{i}$ & $\begin{array}{l}\infty \\
\infty \\
0 \\
0\end{array}$ & $\hat{\theta}$ & $\underset{\exists}{\Xi}$ & $\stackrel{\text { ge }}{=}$ & $\stackrel{n}{n}$ & $\stackrel{n}{i}$ & \begin{tabular}{l}
\multirow{b}{0}{} \\
$\stackrel{0}{0}$
\end{tabular} & $\underset{i}{\stackrel{N}{i n}}$ & ஸु. & ले & $\begin{array}{l}\text { m. } \\
\text { in }\end{array}$ & $\stackrel{n}{i}$ \\
\hline$\tilde{Z}$ & $\begin{array}{l}n \\
\stackrel{\dot{H}}{n}\end{array}$ & $\begin{array}{r}\underset{\sim}{\sim} \\
\underset{f}{ }\end{array}$ & $\underset{\text { d. }}{\vec{m}}$ & $\begin{array}{l}\text { है } \\
\text { iे } \\
\text { in }\end{array}$ & $\begin{array}{l}\text { nె } \\
\infty \\
\infty\end{array}$ & $\begin{array}{l}\text { કे } \\
\text { さ }\end{array}$ & $\begin{array}{l}0 \\
\infty \\
\infty\end{array}$ & $\begin{array}{l}8 \\
\text { : } \\
\dot{+}\end{array}$ & $\frac{\grave{m}}{\dot{m}}$ & 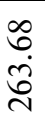 & $\begin{array}{l}n \\
\infty \\
\hat{d} \\
0\end{array}$ & $\begin{array}{l}\text { mे } \\
\text { ñ } \\
\text { ñ }\end{array}$ & 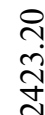 \\
\hline
\end{tabular}

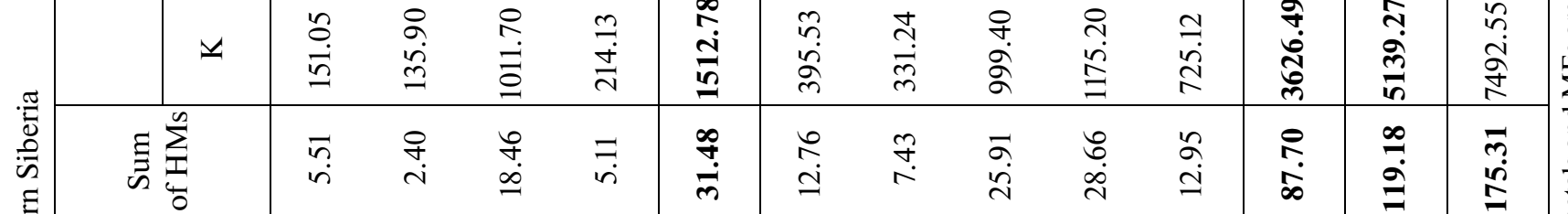

\begin{tabular}{|c|c|c|c|c|c|c|c|c|c|c|c|c|c|}
\hline 2 & ¿à. & \begin{tabular}{l}
8 \\
\hdashline \\
0
\end{tabular} & \begin{tabular}{l}
8 \\
\hdashline \\
0
\end{tabular} & $\begin{array}{l}8 \\
\vdots \\
0\end{array}$ & @̊̀. & $\begin{array}{l}8 \\
0 \\
0\end{array}$ & స్ & $\begin{array}{l}8 \\
\vdots \\
0\end{array}$ & $\begin{array}{l}8 \\
8 \\
0\end{array}$ & $\begin{array}{l}\tilde{\sigma} \\
0 \\
0\end{array}$ & 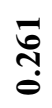 & ঙֶ. & 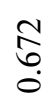 \\
\hline $\bar{Z}$ & $\begin{array}{l}\hat{8} \\
0 \\
0\end{array}$ & $\begin{array}{l}\tilde{\delta} \\
\text {. }\end{array}$ & $\begin{array}{l}\stackrel{0}{0} \\
\stackrel{0}{0}\end{array}$ & $\begin{array}{l}\infty \\
\stackrel{0}{0} \\
0\end{array}$ & $\stackrel{n}{\text { On }}$ & 훙 & $\begin{array}{l}8 \\
8 \\
0\end{array}$ & $\begin{array}{l}F \\
0 \\
0\end{array}$ & $\begin{array}{l}\text { ఠె } \\
0 \\
0\end{array}$ & $\begin{array}{l}8 \\
0 \\
0\end{array}$ & ڤ̊. & $\stackrel{n}{0}$ & $\frac{\infty}{0}$ \\
\hline
\end{tabular}

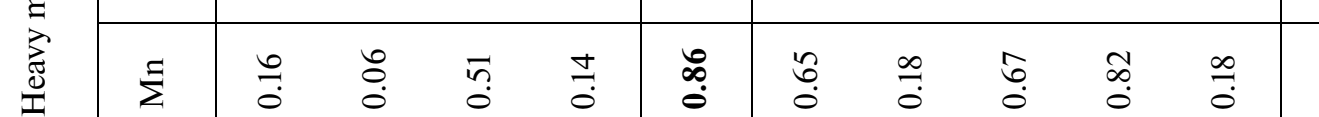

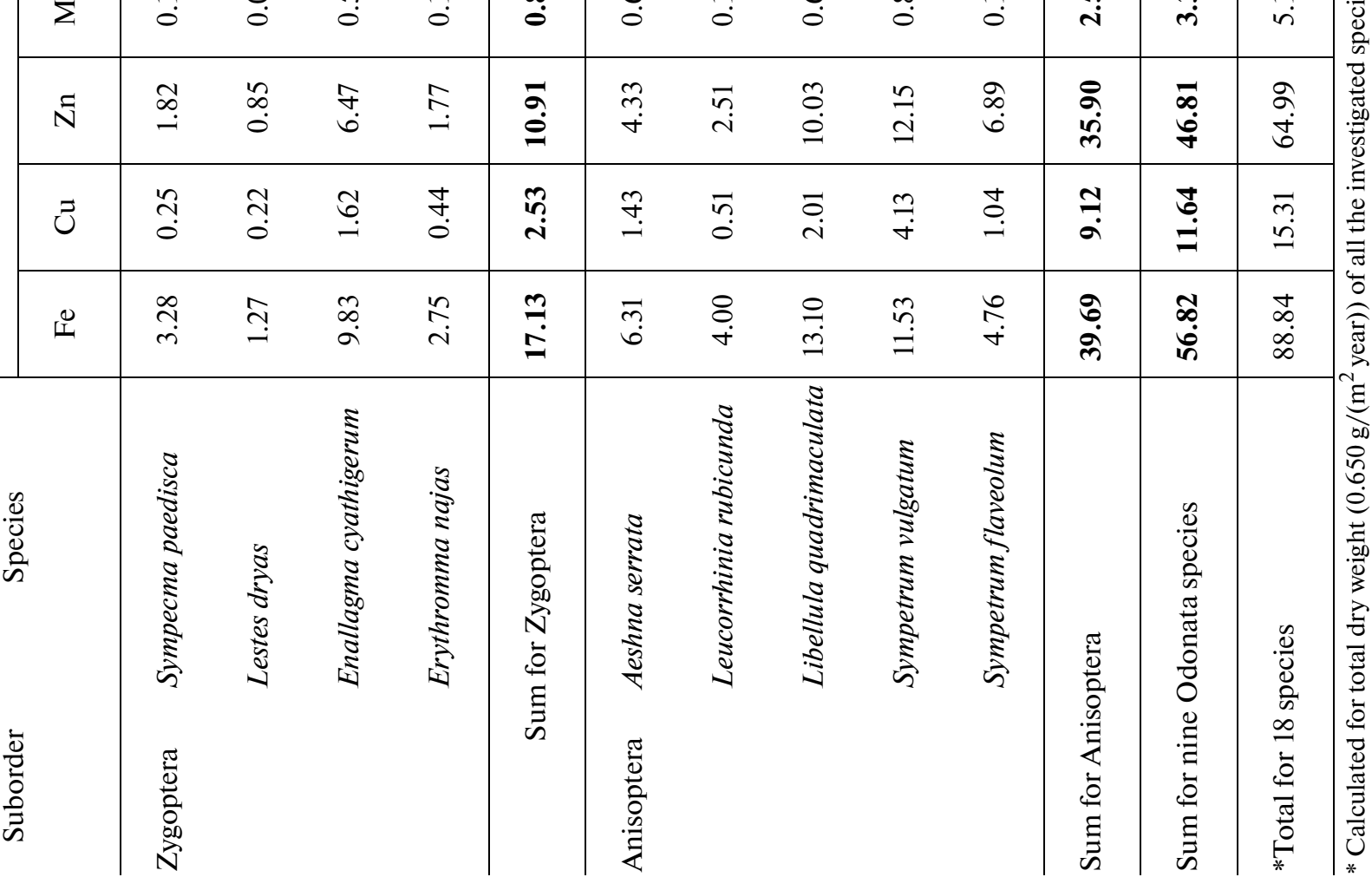




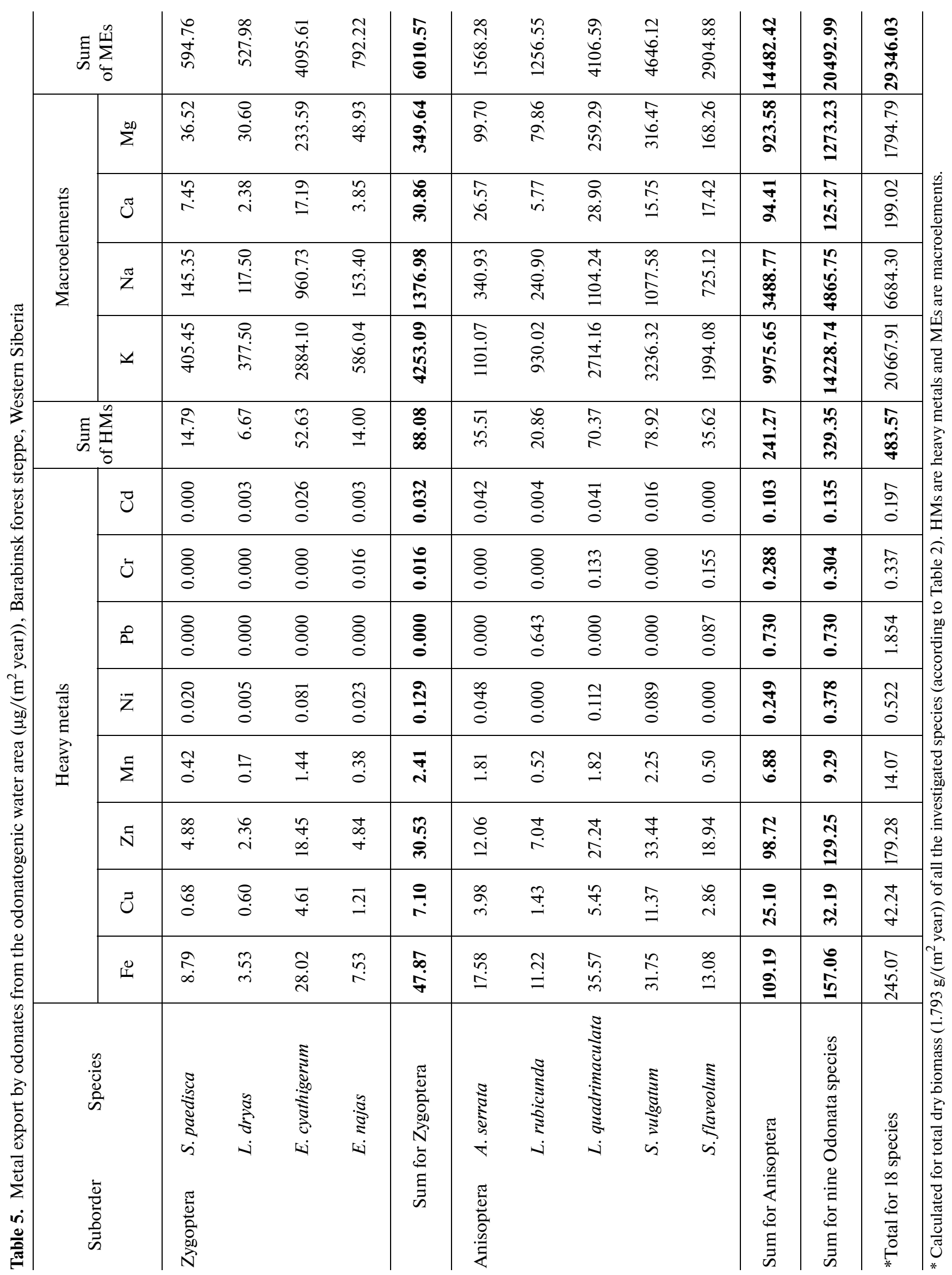

CONTEMPORARY PROBLEMS OF ECOLOGY Vol. 9 No.4 2016 
$0.35 \mathrm{~g} /\left(\mathrm{m}^{2}\right.$ year $)$ of dry weight for culicomorphous insects (suborder Nematocera: Chironomidae, Ceratopogonidae, and Chaoboridae) (Demina, 2014).

In some odonate species, the amplitude of interannual fluctuations of abundance was very high, while in other species it was very low. For instance, the maximum abundance was different from the minimum one by 51 times in $C$. lunulatum, by 43 times in E. cyathigerum, and by 42 times in L. quadrimaculata, while in $A$. serrata and $S$. danae this difference was only 3.6 and 4.2 times, respectively, and in $C$. pulchellum and $L$. sponsa the difference was 5.3 times; the other species had an average difference between the maximum and minimum abundances from 6 times to 21 times. For all the odonate population, the maximum flux of abundance was different from the minimum one only by 8 times, including a small difference for suborder Anisoptera (5 times) and Zygoptera (9 times). Therefore, the total flux of organic matter from aquatic to terrestrial ecosystems remains relatively stable irrespective of interannual variations in the abundance of separate species. In addition, emergence expressed through biomass had a lower (sixfold) amplitude of interannual fluctuations.

The abundance of odonates is directly associated with the level of water content in the area: during the rise of water level, the number of water bodies increases and habitat conditions for larvae improve in them, which leads to an increase in the abundance of odonates, and the opposite picture is observed during the fall of water level. Therefore, lake natural cycles inherent in Western Siberia on the whole are extremely important for odonates. The aquatic ecosystems of the Barabinsk forest steppe are characterized by an unstable water regime; Lake Chany is a demonstrative indicator of manifestation of transgressive-regressive phases of territorial wetting. Chany is a so-called pulsing lake that has several cycles of water level fluctuations, with the maximum cycle being about 100 years and the minimum cycle being $2-4$ years, and a number of intermediate cycles (Pulsiruyushchee ozero Chany, 1982; Ekologiya ozera Chany, 1986). It was previously established that the abundance of populations of the overwhelming majority of the investigated odonate species is strongly related to the water balance of Lake Chany (Popova and Haritonov, 2010). Thus, 14 of the 18 investigated species have significant correlation coefficients, which range from 0.4 to 1 , and only four species have insignificant correlation coefficients (in the range from 0.1 to 0.3 ). The maximum value of the coefficient $(r=0.9)$ was recorded in L. Quadrimaculata; like in most other species its abundance may be maximal 1-2 years after the water reaches the maximum level (Popova and Haritonov, 2010).

It is important to note that the maximum migration activity of odonates is observed during years characterized by the largest abundance. Thus, mass migra- tions have been recorded for some Baraba species (L. quadrimaculata, Lerrathia, pectoralis, L. rubicunda, Sympen, danae, S. flaveolum, S. vulgatum, and Aeshnt mixta); i.e., a great number of individuals are observed to be expelled from overpopulated habitats; under these conditions, the absolute majority of migrants die, and only a few of them migrate to new areas (Haritonov and Popova, 2011). Another variety of the migration activity of odonates, including Sympetrum danae and $S$. vulgatum in Baraba, is their capability for mass reproductive movements (Popova and Haritonov, 2014). Such dispersion strategies of odonates optimize the abundance of populations, especially in areas with an unstable level of water content, and increase the intensity of export of chemical elements and organic matter from eutrophic water bodies.

The basic emergence $(72.5 \%)$ was provided by eight species, which were leading both with respect to abundance and with respect to biomass: four Anisoptera species (L. quadrimaculata, S. flaveolum, S. vulgatum, and $S$. danae) and four Zygoptera species (C. lunulatum, E. cyathigerum, L. sponsa, and S. paedisca). These are broad-range species. On the investigated territory, they occurred in a wide range of biotopes. Apparently, the habitat versatility of the species is one of the leading factors of its widespread occurrence and the high density of its spatial distribution, which has already been emphasized by other authors (Harabiš and Dolný, 2010).

In some works, odonate larvae occupy the last positions (with respect to their abundance to a greater extent and with respect to their biomass to a lesser extent due to their large sizes) among other amphibionts. This estimate is quite objective when the matter concerns watercourses in which amphibiotic insects are usually dominated by Diptera, Trichoptera, Plecoptera, or Ephemeroptera. However, when we consider semiflowing and, in particular, standing (temporary) water bodies, this estimate appears to be wrongly underestimated due to the application of inadequate methods with respect to odonates, since large sizes of larvae, their high motility, and reaction rate are not taken into account in this case, and it is also not considered that the spatial distribution of odonate larvae is equally of a random and aggregated nature.

In our studies the emergence of odonates was estimated based on an investigation of the imago population. A large number of imago samples (16 721 samples over 31 years) leveled the irregularity in the spatial distribution of individuals. It is impossible to perform such a great number of larval samples for the same purposes due to their high labor and time requirements compared with adult insect samples. In addition, our calculations of odonate emergence were based not just on the average annual abundance (which is, in turn, averaged over all the investigated biotopes), which reflects only a portion of the entire 
biomass of odonates that emerged from a water body, but also on application of Haritonov's coefficient $R_{\mathrm{S}}$, which takes into account the renewability of fluxes of organic matter. It was initially calculated as the ratio of the period of mass emergence $\left(D_{\mathrm{S}}\right)$ per year to the lifetime of imago of this species $\left(L_{\mathrm{S}}\right)$. On the whole, the value of this coefficient was species-specific and varied from 2 to 4 in different species. We further paid attention to the fact that these estimated values of the coefficient coincided almost completely with the number of emergence peaks and imago flight peaks for each species and for each year. The two latter events are closely related in the life of odonates: mass emergence of the species is usually followed by the mass flight of this species on the same or next day.

Of course, the influx of emerging odonates and other insects is much smaller than primary terrestrial productivity. For example, the long-term annual average maximum emergence of odonates in Prichanov area (283.6 t/year in dry weight) was only about $0.04 \%$ of terrestrial plant productivity (643900 t/year). The latter was calculated based on data on the terrestrial productivity of forb-grass-reed bogs $\left(2092 \mathrm{~g} / \mathrm{m}^{2}\right)$ (Kosykh, 2009) and steppificated forb-grass-gramineous meadows $\left(430 \mathrm{~g} / \mathrm{m}^{2}\right)$ (Titlyanova, 2007) in the Barabinsk steppe, as well as on data on terrestrial productivity of broad-leaved forests and shrubs $\left(19000 \mathrm{~g} / \mathrm{m}^{2}\right)$ (Pokarzhevskii, 1985) in the forest and forest-steppe zones; the areas occupied by these plant associations on the investigated forest-steppe site were also taken into account. It is interesting that the same share $(0.04 \%)$ was obtained during the emergence of the insects in the near-shore area of Lake Michigan (MacKenzie and Kaster, 2004).

If we assume the secondary terrestrial productivity (namely, first-order consumers) to be a unit of comparison, the influx of aquatic resources that enter terrestrial ecosystems during emergence of amphibiotic insects may be 3 times higher than the influx of productivity of herbivorous insects (Gray, 1989). Unfortunately, we have no data on the productivity of terrestrial insects on the study site of the Barabinsk forest steppe. However, we can make formal comparison, irrespective of the territory, if we apply an index such as the carbon percentage of dry weight: Odonata 52 $54 \%$ (our data), Coleoptera $37-56 \%$, Lepidoptera 44-57\%, and Hymenoptera 47-57\% (Pokarzhevskii, 1985). That is, on average, carbon concentrations are 4-5\% higher in odonates than those in terrestrial beetles, butterflies, and Hymenoptera.

In our research the total content of both all metals and separate elements in suborder Zygoptera $(275.3 \mu \mathrm{g} / \mathrm{g}$ of dry weight per 1 averaged Zygoptera species) for all metals was almost the same as that in suborder Anisoptera $(265.2 \mu \mathrm{g} / \mathrm{g}$ of dry weight per 1 averaged Anisoptera species for all metals) (Table 3), although, a priori, Anisoptera had been assumed to prevail in concentration (both total and with respect to separate elements) of metals, which is due to the specific character of the movement of dragon-fly larvae: in addition to the ability to move by feet along a substrate or by swimming, which is inherent in all Odonata larvae, larvae of suborder Anisoptera can make reactive movements based on the vacuum-pump principle, i.e., when water is first soaked into the rectum through the rectal orifice and is then discharged outwards under the head. During these movements, in addition to water-dissolved oxygen, other elements may enter the insect organism, including HMs, while the organism of larvae of suborder Zygoptera may acquire chemical elements only together with food. It should also be noted that, except for the general type of diet for all Odonata (obligate predators), larvae of these suborders are significantly different by their appearance and sizes (on the average, Anisoptera larvae are of a larger size than Zygoptera larvae) and biotopical confinement (Anisoptera larvae are included in phytophilous, near-bottom, and benthic communities, while Zygoptera larvae are included only in phytophilous communities).

The interspecific differences in the total content of all metals were insignificant: the minimum and maximum values were 202.4 (S. flaveolum) and 344.7 (A. serrata) $\mu \mathrm{g} / \mathrm{g}$ of dry weight for HMs and $11662(S$. paedisca) and 21443 (E. cyathigerum) $\mu \mathrm{g} / \mathrm{g}$ of dry weight for MEs (Table 3). The species specifieity was clearly revealed in preferential accumulation of separate elements by some odonate species or, on the contrary, in their absence in other odonate species. Such differences may hardly be associated with food composition, since odonate larvae are practically opportunistic predators: they consume any living animal feed they can physically cope with. In some cases, elective metal accumulation by species may be due to the local concentration of metals in water bodies. For instance, the recorded maximum of $\mathrm{Pb}$ in L. rubicunda, whose concentration is below the analytical detection limit in most cases, may indicate local pollution or selectivity in metal accumulation by this species, which requires further research. In any case, $\mathrm{Pb}$ exported by some odonate species may be dangerous for swimming birds that nest on lake shores in the Barabinsk forest steppe. However, the content of $\mathrm{Pb}$ in the odonates investigated by us does not exceed the maximum level (10 $\mu \mathrm{g} / \mathrm{g}$ of dry weight) established for feed of domestic animals: rodents, poultry, and fish (Mineral tolerance..., 2005). According to other sources, $\mathrm{Pb}$ concentration in feed at a rate of less than $100 \mu \mathrm{g} / \mathrm{g}$ of dry weight does not influence birds breeding (cit. by Eeva and Lehikoinen, 1996).

The content of $\mathrm{Cd}, \mathrm{Ca}, \mathrm{Cr}, \mathrm{Co}, \mathrm{Cu}, \mathrm{Fe}, \mathrm{Mg}, \mathrm{Mn}$, and $\mathrm{Ni}$ in odonates in the Barabinsk forest steppe also does not exceed the maximum level established for animal bird and rodent feeding (Mineral tolerance..., 2005), except for insignificant potassium excess (the established norm is $10 \mathrm{mg} / \mathrm{g}$ of dry weight). Nickel concentrations of over $300 \mathrm{mg} / \mathrm{kg}$ of dry weight in a 
diet were observed to cause a decrease in growth rate in newly hatched chickens. Dietary Cd concentrations of $20 \mathrm{mg} / \mathrm{kg}$ of dry weight caused kidney lesions and anemia in mallard ducklings (cit. by Eeva and Lehikoinen, 1996).

On average, the Odonata representatives investigated by us contained more HMs than Coenagrion puella odonates (suborder Zygoptera) at the national park in Poland (Boron and Miroslawski, 2009): the content of $\mathrm{Fe}$ and $\mathrm{Cu}$ was three times higher and the content of $\mathrm{Cu}$ and $\mathrm{Mn}$ was almost two times higher (Table 6). Specifically, the Cd concentration in the odonate imago in the Barabinsk forest steppe was 20 times lower than the established background value for $C$. puella. However, on the HM-polluted site of the industrial area (Boron and Miroslawski, 2009), the content of most of elements in odonates exceeds that in odonates in the forest-steppe zone of Western Siberia. In one of the Canadian lakes in the northwest of the province of Ontario, the content of this element is also observed to have increased in emerged odonates (by 3 times) after the experimental addition of $\mathrm{Cd}$ (Currie et al., 1997), compared with the average value obtained by us for odonates in the Barabinsk forest steppe. The content of metals in the odonate species investigated by us does not generally exceed that in bugs (Hemiptera) in Canadian and Finnish water bodies (Scheuhammer et al., 1997; Nummelin et al., 2007) and in beetles (Coleoptera) in Canadian water bodies (Scheuhammer et al., 1997). Odonates in Western Siberia contain more $\mathrm{Fe}, \mathrm{Zn}, \mathrm{Ni}, \mathrm{Pb}$, and $\mathrm{Cd}$ than beetles of Dytiscidae family in the background area in Spain (Burghelea et al., 2011). The average content of $\mathrm{Pb}$ in Odonata representatives collected in the Barabinsk forest-steppe area is almost twice as high as that in bugs of Gerridae family (water strides) and beetles of Gyrinidae family (gyrinids) in water bodies of Canada (Scheuhammer et al., 1997) and six times higher than in beetles of Dytiscidae family (diving beetles) in Spanish rice fields (Burghelea et al., 2011), which is determined by the elevated concentration of this element in the body of L. rubicunda (Table 3). However, the recorded maximum content of $\mathrm{Pb}$ does not exceed the concentration of this element in Coenagrion puella inhabiting the contaminated territory of Verkhnesilizski industrial area (Poland) (Borona and Miroslawski, 2009) and in bugs of Notonectidae family in water bodies and wetlands of Canada (Scheuhammer et al., 1997).

Studies of the specificity of metal accumulation by different species and taxa of aquatic insects were carried out during the exposure of larvae in water with HM additions (Tollet et al., 2009). It was found that larvae of Pachydiplax longipennis and Erythemis simplicicollis (Anisoptera: Libellulidae) odonates are more tolerant to HM effects than other aquatic invertebrates and can accumulate very large concentrations of $\mathrm{Pb}, \mathrm{Cd}$, and $\mathrm{Cu}(>1000 \mu \mathrm{g} / \mathrm{g}$ of dry weight); in addition, the larvae are more sensitive to $\mathrm{Cu}$ accumulation than to $\mathrm{Pb}$ and $\mathrm{Cd}$ accumulation, which the authors explain by the ability of aquatic insects to quickly accumulate copper (Tollet et al., 2009). This feature is possibly determined by the quicker interaction of copper with metal-binding proteins. It was experimentally shown (Poteat and Buchwalter, 2014; Poteat et al., 2015 ) that the rate and efficiency of accumulation of dissolved HMs by larvae of caddis flies, dayflies, and stoneflies is determined by their body size and mass and phylogeny (at the level of orders). In addition, a large variability in HM accumulation was recorded between species of the same family or even the same genus. It is assumed that such differences may also be associated with different feed sources. For instance, dayflies belonging to the same genus may be different in regards to the type of their diet (Poteat et al., 2015).

The amount $\left(\mu \mathrm{g} /\left(\mathrm{m}^{2}\right.\right.$ year $\left.)\right)$ of HMs exported by odonates in the Barabinsk Steppe to the land area or from the water area $\left(\mathrm{g} / \mathrm{m}^{2}\right)$ decreases in the sequence $\mathrm{Fe}>\mathrm{Zn}>\mathrm{Cu}>\mathrm{Mn}>\mathrm{Pb}>\mathrm{Ni}>\mathrm{Cr}>\mathrm{Cd}$, while the amount of microelements decreases in the sequence $\mathrm{K}>\mathrm{Na}>\mathrm{Mg}>\mathrm{Ca}$ (Tables 4, 5). The average content of metals in odonates decreases in the same row (see above). However, the content of metal and its export do not always have direct correlations (the abovedescribed analogy with the abundance and biomass of odonates may also be observed, i.e., when the abundance of the species may be low, while the extracted biomass may be high). For instance, among the nine investigated species, the highest $\mathrm{Fe}$ concentration was revealed in $S$. paedisca (172.4 $\mu \mathrm{g} / \mathrm{g}$ of dry weight), while the lowest concentration was found in $S$. flaveolum (74.3), which, on the other hand, makes a larger contribution $\left(4.8 \mu \mathrm{g} /\left(\mathrm{m}^{2}\right.\right.$ year $)$ in dry weight $)$ to the export of Fe than $S$. paedisca (3.3) does; in turn, the largest contribution with respect to export of $\mathrm{Fe}$ is made by $L$. quadrimaculata species (13.1), which occupies the intermediate position with respect to Fe content among other species $(137.8 \mu \mathrm{g} / \mathrm{g})$. Here, a positive correlation between the exported biomass and the export of metals is observed: a larger odonate biomass (which is generally characteristic of dragon flies) involves the export of a larger amount of metals contained in them. Accordingly, the above-described proportion with respect to the contribution of the two suborders to the export of water productivity remains the same: the total volume of organic matter exported by representatives of suborder Anisoptera is two times higher than that exported by representatives of suborder Zygoptera, including the export of metals, which is three times higher in representatives of Anisoptera than that in representatives of Zygoptera.

During the experimental addition of cadmium chloride to the lake ecosystem, we estimated the export of $\mathrm{Cd}$ from bottom sediments by aquatic insects (Currie et al., 1997). The work being cited used literature data on the productivity of the investigated insect groups. It was shown that potential export of $\mathrm{Cd}$ by 
odonate imagoes may be from 0.0019 to $4.4 \mu \mathrm{g} /\left(\mathrm{m}^{2}\right.$ year) during their minimum and maximum productivity, respectively. The value of export of $\mathrm{Cd}$ was $3.3 \mu \mathrm{g} /\left(\mathrm{m}^{2}\right.$ year $)$ for Diptera imagoes and from 0.3 to 2.9 for Epheroptera. Therefore, the value of Cd export from the water area per $1 \mathrm{~m}^{2}$ that is made by odonates in the Barabinsk forest steppe is 21 times lower than the maximum export of this metal by odonates in the Canadian lake (Currie et al., 1997).

According to the 5-point scale of ecological indices on the content of chemical elements in different food links ( 1 point relative well-being, 2 points risk, 3 points crisis, 4 points disaster, and 5 points catastrophe), the Barabinsk forest steppe is classified as an ecological risk zone; the Baraba soils have a middle level of content of macro- and microelements (Il'in and Syso, 2001). The three basic types of Barabinsk soil, namely, chernozems, meadow-chernozem soils, and solonetzic soils, have the following average content of heavy metals considered in this work: $\mathrm{Cu} 24.1, \mathrm{Zn}$ 70.6, Mn 775, Ni 39.3, Pb 19.7, Cr 95.1, and Cd 0.17, total $1023.97 \mu \mathrm{g} / \mathrm{kg}$; these values only slightly exceed the state soil standards (Il'in and Syso, 2001). On average, $86.5 \mu \mathrm{g} / \mathrm{m}^{2}$ of these metals annually enter Barabinsk landscapes through odonate emergence. Although we deal with different dimensions ( $\mathrm{mg} / \mathrm{kg}$ of soil in one case and $\mu \mathrm{g} / \mathrm{m}^{2}$ in the other case), one can still make an approximate estimate on odonate contribution (taking into account the ways Odonata utilizes through food chains) to the total content of these metals in the investigated locality. This contribution is quantitatively small, being only $0.01 \%$, and is possibly not that important for biogeocenosis in general; however, it is essential for a toxicological assessment of feeding of higher-order consumers whose diet includes odonates. For instance, as was already noted above (Tollet et al., 2009), and also according to our data, odonates as aquatic insects can accumulate large concentrations of $\mathrm{Pb}, \mathrm{Cd}$, and $\mathrm{Cu}$.

\section{CONCLUSIONS}

The presented research on biomass and metal export by odonates from aquatic to terrestrial ecosystems, which was conducted not just in the near-shore zone of a water body, but on a larger territory (272 $\mathrm{km}^{2}$ ) that also includes the water area and land area, is almost unprecedented in the world scientific literature.

Over the entire period of research, i.e., from 1980 to 2010 , the total average annual abundance of the odonate population in the Barabinsk forest steppe in Western Siberia varied in a rather wide range from 3.0 to 23.2 individuals $/ \mathrm{m}^{2}$, with the average value being 8.3 individuals $/ \mathrm{m}^{2}$.

Irrespective of large interannual variations of the abundance of separate species (e.g., 51-fold interannual variability in Coenagrion lunulatum), the general flux of organic matter from aquatic to terrestrial ecosystems remains relatively stable (sixfold interannual variability).

The maximum total emergence of odonates (283.6 t/year in dry weight) was only $0.04 \%$ of the total terrestrial primary (plant) productivity; however, it is comparable to or may even be higher than the influx of terrestrial secondary productivity, namely, productivity of first-order consumers (herbivorous insects). The export of biomass by odonates from the odonatogenic water area $\left(\mathrm{g} /\left(\mathrm{m}^{2}\right.\right.$ year $\left.)\right)$ was $2.3-13.3$ (at an average value of $5.9 \pm 0.4)$ in wet weight and $0.7-4.1(1.8 \pm$ 0.1 ) in dry weight, which is $4-5$ times higher than that in Diptera representatives.

The content of metals $(\mu \mathrm{g} / \mathrm{g})$ in Barabinsk foreststeppe odonates and their export $\left(\mu \mathrm{g} /\left(\mathrm{m}^{2}\right.\right.$ year $\left.)\right)$ from water bodies to the land area decreases in the sequence $\mathrm{K}>\mathrm{Na}>\mathrm{Mg}>\mathrm{Ca}>\mathrm{Fe}>\mathrm{Zn}>\mathrm{Cu}>\mathrm{Mn}>\mathrm{Pb}>\mathrm{Ni}>$ $\mathrm{Cr}>\mathrm{Cd}$.

The content of metals in Barabinsk forest-steppe odonates does not exceed the maximum level established for feeds of domestic animals (rodents, birds, and fish).

We revealed selectivity in the accumulation of elements by different odonate species (even those belonging to the same genus), which is likely due to genetic factors (species affiliation) rather than to food composition.

There are almost no differences in metal accumulation at the level of suborders, except for $\mathrm{Pb}$, which was present only in odonates of the suborder Anisoptera. However, due to their large biomass, the total volume of organic matter exported by representatives of suborder Anisoptera is two times larger than that exported by representatives of suborder Zygoptera; specifically, the volume of metals exported by representatives of the first suborder is three times larger than that exported by representatives of the second suborder.

The obtained high values of odonate emergence from water bodies in the Barabinsk forest steppe, together with their high migration activity, ecological plasticity, and ability to colonize a wide range of types of water bodies (especially numerous temporary water bodies), show a significant contribution of Odonata to fluxes of water productivity, including metals, to the land area and also confirm the export of these products at significant distances from the emergence sites.

\section{ACKNOWLEDGMENTS}

This research was supported by the Foundation for Scientific Research, the program of state academies of sciences for 2013-2020, projects nos. VI.51.1.9 and 51.1.1. 


\section{REFERENCES}

Alimov, A.F., Elementy teorii funktsionirovaniya vodnykh ekosistem (Elements of the Theory of Functions of Aquatic Ecosystems), St. Petersburg: Nauka, 2000.

Ballinger, A. and Lake, P.S., Energy and nutrient fluxes from rivers and streams into terrestrial food webs, Mar. Freshwater Res., 2006, no. 57, pp. 15-28.

Baxter, C.V., Fausch, K.D., and Saunders, W.C., Tangled webs: reciprocal flows of invertebrate prey link streams and riparian zones, Freshwater Biol., 2005, no. 50, pp. 201-220.

Bennett, S. and Mill, P.J., Pre- and post-maturation survival in adults of the damselfly Pyrrhosoma nymphula (Zygoptera: Coenagrionidae), J. Zool., 1995, no. 235, pp. 559-575.

Bried, J.T. and Ervin, G.N., Note to abundance patterns of dragonflies along a wetland buffer, Wetlands, 2006, vol. 26 , no. 3, pp. 878-883.

Boroń, M. and Mirosławski, J., Using insects (damselflies: azajre damselfly, Coenagrion puella) as biomarkers of environmental pollution, Fresenius Environ. Bull., 2009, vol. 18 , no. 7, pp. $1219-1225$.

Buckner, J.S. and Hagen, M.M., Triacylglycerol and phospholipid fatty acids of the silverleaf whitefly: composition and biosynthesis, Arch. Insect Biochem. Physiol., 2003, no. 53, pp. 66-79.

Burghelea, C.I., Zaharescu, D.G., Hoodac, P.S., and Palanca-Soler, A., Predatory aquatic beetles, suitable trace elements bioindicators, J. Environ. Monit., 2011, vol. 13, pp. 1308-1315.

Clark, T.E. and Samways, M.J., Dragonflies (Odonata) as indicators of biotope quality in the Kruger National Park, South Africa, J. Appl. Ecol., 1996, no. 33, pp. 1001-1012.

Conrad, K.F., Willson, K.H., Harvey, I.F., Thomas, C.J., and Sherratt, T.N., Dispersal characteristics of seven odonate species in an agricultural landscape, Ecography, 1999, vol. 22, pp. 524-531.

Corbet, P.S., An adult population study of Pyrrhosoma nymphula (Sulzer): (Odonata: Coenagrionidae), $J$. Anim. Ecol., 1952, vol. 21, pp. 206-222.

Corbet, P.S., Dragonflies: Behavior and Ecology of Odonata, Colchester: Harley Books, 1999.

Corbi, J.J. and Froehlich, C.G., Bioaccumulation of metals in aquatic insects of streams located in areas with sugar cane cultivation, Quim. Nova, 2010, vol. 33, no. 3, pp. 644-648.

Corbi, J.J., Froehlich, C.G., Trivinho-Strixino, S., and dos Santos, A., Evaluating the use of predatory insects as bioindicators of metals contamination due to sugarcane cultivation in neotropical streams, Environ. Monit. Assess., 2011, vol. 177, pp. 545-554.

Currie, R.S., Fairchild, W.L. and Muir, D.C.G., Remobilization and export of cadmium from lake sediments by emerging insects, Environ. Toxicol. Chem., 1997, vol. 16, no. 11, pp. 2333-2338.

Djomina, I.V., Role of culicomorph insects (Diptera, Nematocera) in formation of the matter and energy flows through the "water-air" border of the floodplain lakes of the Volga River (Saratov oblast), Cand. Sci. (Biol.) Dissertation, Saratov, 2014.
Eeva, T. and Lehikoinen, E., Growth and mortality of nestling great tits (Parus major) and pied flycatchers (Ficedula hypoleuca) in a heavy metal pollution gradient, Oecologia, 1996, vol. 108, pp. 631-639.

Ekologiya ozera Chany (Ecology of the Chany Lake), Novosibirsk: Nauka, 1986.

Freitag, H., Composition and longitudinal patterns of aquatic insect emergence in small rivers of Palawan Island, the Philippines, Int. Rev. Hydrobiol., 2004, no 89, pp. 375-391.

Gavrilov, L.A. and Gavrilova, N.S., Biologiya prodolzhitel'nosti zhizni. Kolichestvennye aspekty (Biology of Life Duration: Quantitative Aspects), Moscow: Nauka, 1991.

Gladyshev, M.I., Kharitonov, A.Yu., Popova, O.N., Sushchik, N.N., Makhutova, O.N., and Kalacheva, G.S., Quantitative estimation of dragonfly role in transfer of essential polyunsaturated fatty acids from aquatic to terrestrial ecosystems, Dokl. Biochem. Biophys., 2011, vol. 438, no. 1, pp. 141-143.

Gladyshev, M.I., Sushchik, N.N., Anishchenko, O.V., Makhutova, O.N., Kalachova, G.S., and Gribovskaya, I.V., Benefit-risk ratio of food fish intake as the source of essential fatty acids vs. heavy metals: a case study of Siberian grayling from the Yenisei River, Food Chem., 2009, vol. 115, pp. 545-550.

GOST (State Standard) 26570-95: Interstate Standard. Fodder, Mixed Fodders, and Mixed Fodder Sources. FlamePhotometric Analysis of Calcium Content, Minsk: Mezhgos. Sovet Standart., Metrol., Sertifikats., 1995.

GOST (State Standard) 30503-97: Interstate Standard. Fodder, Mixed Fodders, and Mixed Fodder Sources. FlamePhotometric Analysis of Sodium Content, Minsk: Mezhgos. Sovet Standart., Metrol., Sertifikats., 1997.GOST (State Standard) 30504-97: Interstate Standard. Fodder, Mixed Fodders, and Mixed Fodder Sources. Flame-Photometric Analysis of Potassium Content, Minsk: Mezhgos. Sovet Standart., Metrol., Sertifikats., 1998. GOST (State Standard) 30502-97: Interstate Standard. Fodder, Mixed Fodders, and Mixed Fodder Sources. Flame-Photometric Analysis of Magnesium Content, Minsk: Mezhgos. Sovet Standart., Metrol., Sertifikats., 1998.

GOST (State Standard) 30692-2000: Interstate Standard. Fodder, Mixed Fodders, and Mixed Fodder Sources. Flame-Photometric Analysis of Cooper, Lead, Zink, and Cadmium Content, Minsk: Mezhgos. Sovet Standart., Metrol., Sertifikats., 2000.

Gratton, C. and Vander Zanden, M.J., Flux of aquatic insect productivity to land: comparison of lentic and lotic ecosystems, Ecology, 2009, no. 90, pp. 26892699.

Gray, L.J., Emergence production and export of aquatic insects from a tallgrass prairie stream, Southwest. Nat., 1989, no. 34, pp. 313-318.

Harabis, F. and Dolny, A., Ecological factors determining the density-distribution of Central European dragonflies (Odonata), Eur. J. Entomol., 2010, no. 107, pp. 571-577.

Haritonov, A. and Popova, O., Spatial displacements of Odonata in south-west Siberia, Int. J. Odonatol., 2011a, vol. 14, no. 1, pp. 1-10. 
Haritonov, A.Yu. and Popova, O.N., Migrations of dragonflies (Odonata) in the south of the West Siberian plain, Entomol. Rev., 2011b, vol. 91, no. 4, pp. 411-419.

Il'in, V.B. and Syso, A.I., Mikroelementy i tyazhelye metally $v$ pochvakh $i$ rasteniyakh Novosibirskoi oblasti (Trace Elements and Heavy Metals in Soil and Plants of Novosibirsk Oblast), Novosibirsk: Sib. Otd., Ross. Akad. Nauk, 2001.

Kozhanchikov, I.V., Metody issledovaniya ekologii nasekomykh (Analysis Methods of Insect Ecology), Moscow: Vysshaya Shkola, 1961.

Lavilla, I., Rodríguez-Liñares, G., Garridob, J., and Bendichoa, C., A biogeochemical approach to understanding the accumulation patterns of trace elements in three species of dragonfly larvae: evaluation as biomonitors, J. Environ. Monit., 2010, vol. 12, pp. 724-730.

Leeper, D.A. and Taylor, B.E., Insect emergence from a South Carolina (USA) temporary wetland pond, with emphasis on the Chironomidae (Diptera), J. North Am. Benthol. Soc., 1998, no. 17, pp. 54-72.

Lekyavichus, E., Information status of an ecosystem, in Ekologicheskii prognoz (Ecological Forecast), Moscow: Mosk. Gos. Univ., 1986, pp. 157-163.

MacKenzie, R.A. and Kaster, J.L., Temporal and spatial patterns of insect emergence from a Lake Michigan coastal wetland, Wetlands, 2004, no. 24, pp. 688-700.

Mineral Tolerance of Animals, Washington, DC: Natl. Acad. Press, 2005,

2nd ed.

Pajunen, V.I., Studies on the population ecology of Leucorrhinia dubia V. D. Lind. (Odonata, Libellulidae), Ann. Zool. Soc., 1962, vol. 24, no. 4, pp. 1-79.

Palii, V.F., Metodika izucheniya fauny i fenologii nasekomykh (Analysis Method of Fauna and Phenology of Insects), Voronezh: Tsentr.-Chernozem. Knizh. Izd., 1970.

Parr, M.J., Comparative studies of Coenagriid (Odonata) population ecology, Proc. XIII Int. Entomological Congr., Moscow, August, 1968, St. Petersburg, 1972, vol. 1, pp. 540-541.

Pesenko, Yu.A., Printsipy i metody kolichestvennogo analiza $v$ faunisticheskikh issledovaniyakh (Principles and Methods of Quantitative Analysis in Faunistic Studies), Moscow: Nauka, 1982.

Pokarzhevskii, A.D., Geokhimicheskaya ekologiya nazemnykh zhivotnykh (Geochemical Ecology of Terrestrial Animals), Moscow: Nauka, 1985.

PopSPELL.N1.; QKe dragonflies of forest-steppe in West Siberia: fauna, ecology, biology, in Odonata: Biology of Dragonflies, Tyagi, B.K., Ed., Madurai, India: Sci. Publ, 2007, pp. 89-104.
Popova, O.N., The dragonfly larva population (Odonata) in a temporal water pond, Euroasian Entomol. J., 2010, vol. 9, no. 2, pp. 239-248.

Popova, O.N. and Haritonov, A.Yu., Population dynamics and migration in the dragonfly Libellula quadrimaculata L.,1758 (Odonata, Libellulidae), Euroasian Entomol. J., 2010, vol. 9, no. 2, pp. 231-238.

Popova, O.N. and Haritonov, A.Yu., Estimation of the carry-over of substances by dragonflies from water bodies to land in the forest-steppe of West Siberia, Contemp. Probl. Ecol., 2012, vol. 5, no. 1, pp. 34-39.

Popova, O.N. and Haritonov, A.Yu., Disclosure of Biotopical Groups in the Population of the Dragonfly Coenagrion armatum (Charpentier, 1840), Contemp. Probl. Ecol., 2014a, vol. 7, no. 2, pp. 175-181.

Popova, O.N. and Haritonov, A.Yu., Mass reproductive wandering of dragonflies of the genus Sympetrum (Odonata, Libellulidae), Entomol. Rev., 2014b, vol. 94, no. 1 , pp. $21-28$.

Poteat, M.D. and Buchwalter, D.B., Phylogeny and size differentially influence dissolved $\mathrm{Cd}$ and $\mathrm{Zn}$ bioaccumulation parameters among closely related aquatic insects, Environ. Sci. Technol., 2014, vol. 48, pp. $5274-5281$.

Poteat, M.D., Jacobus, L.M., and Buchwalter, D.B., The importance of retaining a phylogenetic perspective in traits-based community analyses, Freshwater Biol., 2015, vol. 60, pp. 1330-1339.

Pul'siruyushchee ozero Chany (Pulsating Chany Lake), Leningrad: Nauka, 1982.

Scheuhammer, A.M., McNicol, D.K., Mallory, M.L., and Kerekes, J.J., Relationships between lake chemistry and calcium and trace metal concentrations of aquatic invertebrates eaten by breeding insectivorous waterfowl, Environ. Pollut., 1997, vol. 96, no. 2, pp. 235-241.

Tollett, V.D., Benvenutti, E.L., Deer, L.A., and Rice, T.M., Differential toxicity to $\mathrm{Cd}, \mathrm{Pb}$, and $\mathrm{Cu}$ in dragonfly larvae (Insecta: Odonata), Arch. Environ. Contam. Toxicol., 2009, vol. 56, pp. 77-84.

Ubukata, H., Survivorship curve and annual fluctuation in the size of emerging population of Cordulia aenea amurensis Selys (Odonata: Corduliidae), Jpn. J. Ecol., 1981, no. 31 , pp. $335-346$.

Wang, Y., Lin, D.S., Bolewicz, L., and Connor, W.E., The predominance of polyunsaturated fatty acids in the butterfly Morpho peleides before and after metamorphosis, J. Lipid Res., 2006, no. 47, pp. 530-536.

Zhou, H.Y., Cheung, R.Y.H., Chan, K.M., and Wong, M.H., Metal concentrations in sediments and tilapia collected from inland waters of Hong Kong, Water Res., 1998, vol. 32, pp. 3331-3340.

Translated by D. Zabolotny 